Bioorg Med Chem Lett. 2015 April 1; 25(7): 1525-1531. doi:10.1016/j.bmcl.2015.02.018.

\title{
Evaluation of Aconitum diterpenoid alkaloids as antiproliferative agents
}

\author{
Koji Wada ${ }^{a, b}$, Emika Ohkoshi $^{\mathrm{b}}$, Yu Zhao ${ }^{\mathrm{b}}$, Masuo Goto ${ }^{\mathrm{b}}$, Susan L. Morris-Natschke ${ }^{\mathrm{b}}$, and \\ Kuo-Hsiung Lee ${ }^{\mathrm{b}, \mathrm{c},{ }^{*}}$ \\ aSchool of Pharmacy, Hokkaido Pharmaceutical University, 7-1, Katsuraoka-cho, Otaru \\ 047-0264, Japan \\ bNatural Products Research Laboratories, UNC Eshelman School of Pharmacy, University of \\ North Carolina, Chapel Hill, NC 27599-7568, USA \\ ${ }^{\circ}$ Chinese Medicine Research and Development Center, China Medical University and Hospital, \\ Taichung, Taiwan
}

\begin{abstract}
Little information has been reported on the antitumor effects of the diterpenoid alkaloid constituents of Aconitum plants, used in the herbal drug "bushi". This study was aimed at determining the antitumor activities of Aconitum $\mathrm{C}_{19}$-and $\mathrm{C}_{20}$-diterpenoid alkaloids and synthetic derivatives against lung (A549), prostate (DU145), nasopharyngeal (KB), and vincristine-resistant nasopharyngeal (KB-VIN) cancer cell lines. Newly synthesized $\mathrm{C}_{20}$-diterpenoid alkaloid derivatives showed substantial suppressive effects against all human tumor cell lines tested. In contrast, natural and derivatized $\mathrm{C}_{19}$-diterpenoid alkaloids showed only a slight or no effect. Most of the active compounds were hetisine-type $\mathrm{C}_{20}$-diterpenoid alkaloids, specifically kobusine and pseudokobusine analogs with two different substitution patterns, C-11 and C-11,15. Notably, several $\mathrm{C}_{20}$-diterpenoid alkaloids were more potent against multidrug-resistant $\mathrm{KB}$ subline KBVIN cells. Pseudokobusine 11-3'-trifluoromethylbenzoate (94) is a possible promising new lead meriting additional evaluation against multidrug-resistant tumors.
\end{abstract}

\section{Keywords}

Diterpenoid alkaloids; Pseudokobusine; Antiproliferative agents

The genera Aconitum, Consolida and Delphinium (family Ranunculaceae) and the genus Spiraea (family Rosaceae) contain numerous diterpenoid alkaloids, which are classified

\footnotetext{
(C) 2015 Published by Elsevier Ltd.

*Corresponding author. Tel.: +1 919962 0065/0066; fax: +1 919966 3893. khlee@ unc.edu (K.-H. Lee).

Supplementary data

Physical and spectroscopic data for compounds 19-22, 62, 65, 67-70, 79, 93, 95, $106,107$.
}

Publisher's Disclaimer: This is a PDF file of an unedited manuscript that has been accepted for publication. As a service to our customers we are providing this early version of the manuscript. The manuscript will undergo copyediting, typesetting, and review of the resulting proof before it is published in its final citable form. Please note that during the production process errors may be discovered which could affect the content, and all legal disclaimers that apply to the journal pertain. 
structurally as $\mathrm{C}_{18^{-}}, \mathrm{C}_{19^{-}}$, and $\mathrm{C}_{20^{-}}$-diterpenoid alkaloids with the general structures and numbering systems shown in Figure 1., ${ }^{1,2}$ Aconitum plants are used in "bushi", an herbal traditional Chinese medicine prescribed to treat hypometabolism, dysuria, cardiac weakness, chills, neuralgia, gout, and certain rheumatic diseases. ${ }^{3-5}$ Among the $\mathrm{C}_{19}$-diterpenoid alkaloids, aconitine (1), jesaconitine (3), mesaconitine (8), and hypaconitine (9) exhibit particularly high toxicity, while the $\mathrm{C}_{20}$-diterpenoid alkaloids lucidusculine (37), kobusine (51), pseudokobusine (71), and atisine are much less toxic. However, despite the extreme toxicities of some $\mathrm{C}_{19}$-diterpenoid alkaloids, only two studies appeared in the literature in 2005 and 2006. ${ }^{6,7}$ The first reported the antiproliferative activity of 8- $O$-azeloyl-14benzoylaconine, an aconitine-type $\mathrm{C}_{19}$-diterpenoid alkaloid, ${ }^{6}$ and the second described the cytotoxic effects of various $\mathrm{C}_{19}$-diterpenoid alkaloids against tumor cell lines. ${ }^{7}$ Since 2007, many $\mathrm{C}_{19^{-}}$and $\mathrm{C}_{20}$-diterpenoids as well as semisynthetic derivatives were evaluated for cytotoxicity by various assays, including cell growth, clonogenic, cell cycle distribution, and cell cycle-related, against four different human tumor cell lines, A172, A549, HeLa, and Raji. $^{8-12}$

In an initial survey of the pharmacological effects of natural diterpenoid alkaloids and their synthetic derivatives, we tested 108 compounds for antiproliferative activity against four tumor cell lines, lung (A549), prostate (DU145), nasopharyngeal (KB), and vincristineresistant nasopharyngeal (KB-VIN) cancers. Here, we describe our results on the cytotoxic activities of these diterpenoid alkaloids and derivatives.

The $\mathrm{C}_{19}$-diterpenoid alkaloids may be divided into six types: aconitine, lycoctonine pyro, lactone, 7,17-seco, and rearranged. ${ }^{1,2}$ Most of the isolated $\mathrm{C}_{19}$-diterpenoid alkaloids are aconitine- and lycoctonine-types. The $\mathrm{C}_{20}$-diterpenoid alkaloids may be divided into ten types: atisine, denudatine, hetidine, hetisine, vakognavine, napelline, kusnezoline, racemulosine arcutine, and tricalysiamide. ${ }^{1,2}$ Most of the isolated $\mathrm{C}_{20}$-diterpenoid alkaloids are atisine-, hetisine-, and napelline-types. Table 1 lists the natural diterpenoid alkaloids and their source plant as well as the modified diterpenoid alkaloids generated for this study, and Figure 2 gives the structures of compounds 1-108.

We tested 108 diterpenoid alkaloids for antiproliferative effects against four human tumor cell lines [lung carcinoma (A549), prostate carcinoma (DU145), nasopharyngeal (KB), and multi-drug resistant KB subline KB-VIN. Notably, we were interested in the antitumor activities against KB-VIN cells, because they overexpress drug transporter protein Pglycoprotein (P-gp), which effectively reduces intracellular drug concentration, especially of vinca and taxane alkaloids. The compounds included 24 natural $(\mathbf{1}-\mathbf{6}, \mathbf{8}-\mathbf{1 0}, \mathbf{1 2}-\mathbf{1 5}, \mathbf{1 7}, \mathbf{2 3}-$ 25, 28-32, 34, 36) and 12 synthesized $(7,11,16,18-22,26,27,33,35) \mathrm{C}_{19}$-diterpenoid alkaloids, as well as 10 natural $(\mathbf{3 7 - 3 9}, \mathbf{4 1}, \mathbf{4 8}-\mathbf{5 1}, \mathbf{7 1}, \mathbf{8 5})$ and 62 synthesized $(\mathbf{4 0}, \mathbf{4 2}-\mathbf{4 7}$, 52-70, 72-84, 86-108) $\mathrm{C}_{20}$-diterpenoid alkaloids. Paclitaxel, a P-gp substrate anticancer agent, was used as an experimental control. The data are listed in Table 2. P-gpoverexpressing KB-VIN cells were over 100-fold resistant against paclitaxel, demonstrating that a lethal dose of paclitaxel may be required to be effective against MDR phenotype. The ratio of $\mathrm{GI}_{50} \mathrm{~KB} / \mathrm{GI}_{50} \mathrm{~KB}-\mathrm{VIN}$ demonstrated the efficacy of compound against KB-VIN. A549 (lung carcinoma), DU-145 (prostate cancer), and KB (epidermoid carcinoma) cell lines (ATCC) were supplied by Lineberger Comprehensive Cancer Center (UNC-CH). 
Professor Y.-C. Cheng, Yale University, CT generously provided KBvin (vincristineresistant KB subline). Cells were cultured in RPMI 1640 medium containing $25 \mathrm{mM}$ HEPES and $2 \mathrm{mM} \mathrm{L-glutamine} \mathrm{(Mediatech),} \mathrm{supplemented} \mathrm{with} 10 \%$ heat-inactivated fetal bovine serum (Hyclone), $100 \mathrm{IU}$ penicillin, $100 \mu \mathrm{g} / \mathrm{mL}$ streptomycin, and $0.25 \mu \mathrm{g} / \mathrm{mL}$ amphotericin B (Mediatech). KB-VIN cells were grown in media containing $100 \mathrm{nM}$ vincristine and were cultured for 7-10 days without vincristine before experiments were performed. Cells were maintained in a humidified $5 \% \mathrm{CO}_{2}$ atmosphere at $37^{\circ} \mathrm{C}$, and passaged every 3-4 days. Cell viability was determined by the sulforhodamine $\mathrm{B}$ (SRB) colorimetric assay. ${ }^{32}$ In brief, cells (3-5 $\times 10^{3}$ cells/well) were seeded in 96-well plates containing various concentrations of samples or paclitaxel (PXL) as an assay control, and incubated for $72 \mathrm{~h}$. At the end of the exposure period, the attached cells were fixed with 50\% trichloroacetic acid for $30 \mathrm{~min}$ followed by staining with $0.04 \%$ SRB (Sigma Chemical Co.) for $30 \mathrm{~min}$. The bound SRB was solubilized in $10 \mathrm{mM}$ Tris-base and the absorbance was measured at $515 \mathrm{~nm}$ on a Microplate Reader ELx800 (Bio-Tek Instruments, Winooski, VT) with Gen5 software. All results were representative of three or more experiments.

All tested aconitine-type $\mathrm{C}_{19}$-diterpenoid alkaloids, both the natural alkaloids (1-6, 8-10, 12-14) and synthetic analogs $(7,11)$, were inactive $\left(\mathrm{GI}_{50}>20 \mu \mathrm{M}\right)$. Among the lycoctoninetype $\mathrm{C}_{19}$-diterpenoid alkaloids, only compound $\mathbf{3 3}$, esterified with 3-trifluoromethylbenzoyl at C-6, showed any, although very weak, cytotoxic activity with $\mathrm{GI}_{50}$ values of $12.6,14.9$, and $11.9 \mu \mathrm{M}$ against DU145, KB, and KB-VIN cell lines, respectively. The remaining natural alkaloids $(\mathbf{1 5}, \mathbf{1 7}, \mathbf{2 3}-\mathbf{2 5}, \mathbf{2 8}-\mathbf{3 2}, \mathbf{3 4}, \mathbf{3 6})$ and synthetic analogs without a $\mathrm{C}-6$ ester group (16, 18-22, 26, 27, 35) were inactive.

Among the $\mathrm{C}_{20}$-diterpenoid alkaloids, both natural (37-39, 41, 48-50) and synthetic (40, 42-47) napelline-type compounds, as well as hetidine-type synthetic analogs $\mathbf{( 7 2}, \mathbf{7 5}, \mathbf{7 6}$, 100), were inactive. Among hetisine-type $C_{20}$-diterpenoid alkaloids, the natural parent alkaloids 51 and 71, as well as a related synthetic analog (108) of 71, were inactive against all four cancer cell lines. However, appropriate acylation, or in one case, etherification, of the two or three hydroxy groups in $\mathbf{5 1}$ and $\mathbf{7 1}$, respectively, led to cytotoxic synthetic analogs (see Table 1).

Nine different groups were present on hydroxyls of the 11 hetisine-type $\mathrm{C}_{20}$-diterpenoid alkaloids that exhibited average $\mathrm{GI}_{50}$ values of less than $10 \mu \mathrm{M}$ : benzoyl $(\mathbf{5 6}, \mathbf{7 9})$, anisoyl (58), 4-nitrobenzoyl (61, 89), 4-fluorobenzoyl (69), trans-3-trifluoromethylcinnamoyl (70), 3-nitrobenzoyl (93), 3-trifluoromethylbenzoyl (94), cinnamoyl (98), and trityl (107) groups. Nine additional compounds with six different ester groups exhibited average $\mathrm{GI}_{50}$ values between 10 and $20 \mu \mathrm{M}$ : 78 (benzoyl), 81 (anisoyl), 59 (4-nitrobenzoyl), 64, 96 (4trifluoromethylbenzoyl), 65 (4-trifluoromethoxybenzoyl), 84, 86, and 87 (veratroyl). However, all compounds esterified with acetyl $(\mathbf{5 2}, \mathbf{5 3}, \mathbf{7 3}, \mathbf{7 4})$, 2-trifluoromethylbenzoate (62), propyl $(\mathbf{1 0 5}, \mathbf{1 0 6})$, pivaloyl $(\mathbf{1 0 1})$, and nicotinoyl $(\mathbf{6 6}, \mathbf{1 0 2}-104)$ groups, were inactive, regardless of the numbers or positions of the substitution. All six more potent (average $\mathrm{GI}_{50}$ $<10 \mu \mathrm{M})$ derivatives of $\mathbf{7 1}(\mathbf{7 9}, \mathbf{8 9}, \mathbf{9 3}, \mathbf{9 4}, \mathbf{9 8}, \mathbf{1 0 7})$ had a free hydroxy group at C-6.

Comparison of corresponding analogs of $\mathbf{7 1}$ and $\mathbf{5 1}$ showed that some compounds with a C-6 OH rather than $\mathrm{H}$ exhibited higher potency (compare 89 to $\mathbf{5 9 , 9 4}$ to $\mathbf{6 3}$ ), although this pattern was not universal (compare 56 to 79,64 to 96 ). 
Among analogs of 51, esterification of C-15 in addition to C-11 increased potency significantly (compare $\mathbf{5 9}$ to $\mathbf{6 1}$ ) or even converted an inactive to an active compound (compare 54 to 56, 57 to 58, 67 to 69). Consequently, all of the most analogs $(56,58,61,69$, 70) of 51 were esterified at both C-11 and C-15. Among analogs of 71, four C-11 monosubstituted compounds $(\mathbf{8 9}, \mathbf{9 4}, \mathbf{9 8}, \mathbf{1 0 7})$ and two $\mathrm{C}-11,15$ diesterified compounds $(\mathbf{7 9}, \mathbf{9 3})$ exhibited average $\mathrm{GI}_{50}$ values of less than $10 \mu \mathrm{M}$. Certain C-11 $(\mathbf{8 1}, \mathbf{8 4}, \mathbf{9 6}), \mathrm{C}-6,11(\mathbf{7 8}, \mathbf{8 6})$ and C-6,15 (87) esterified compounds were generally less potent, while all C-6 (77, 80, 88. 97) and $\mathrm{C}-15(\mathbf{7 3}, \mathbf{8 5}, \mathbf{9 0}, \mathbf{9 9}, \mathbf{1 0 3}, \mathbf{1 0 5})$ mono-substituted compounds, as well as the trisubstituted analog (92), were inactive. Thus, all of the more active $\left(\mathrm{GI}_{50}<10 \mu \mathrm{M}\right)$ hetisinetype compounds had an ester or ether group on the C-11 hydroxyl and were either 11,15diester analogs of 51 (H at C-6) or 11-monoester/11,15-diester analogs of 71 (OH at C-6).

Striking observations from the data in Table 2 were the degree and comparative ratio of $\mathrm{KB} / \mathrm{KB}$-VIN potency. Eleven compounds $(\mathbf{5 6}, \mathbf{5 8}, \mathbf{6 1}, \mathbf{6 9}, \mathbf{7 0}, \mathbf{7 9}, \mathbf{8 9}, \mathbf{9 3}, \mathbf{9 4}, \mathbf{9 8}$, and 107) were quite potent $\left(\mathrm{GI}_{50}<10 \mu \mathrm{M}\right)$ against KB-VIN. Indeed, compound 70 exhibited a significantly low $\mathrm{GI}_{50}$ value of $3.1 \mu \mathrm{M}$. The ratios of $\mathrm{KB}$ to $\mathrm{KB}-\mathrm{VIN}\left(\mathrm{GI}_{50} \mathrm{~KB} / \mathrm{GI}_{50} \mathrm{~KB}\right.$ VIN) were greater than 0.73 for all active compounds, with many compounds displaying comparable potency against the two cell lines, in contrast with paclitaxel (ratio of 0.0067). $\mathrm{C}_{20}$-Diterpenoid analogs 70, 94, and $\mathbf{1 0 7}$ showed over 1.3-fold selectivity with their greatest cytotoxic activity against $\mathrm{KB}-\mathrm{VIN}\left(\mathrm{GI}_{50} \mathrm{~KB} / \mathrm{GI}_{50} \mathrm{~KB}-\mathrm{VIN}\right.$ : $1.3,1.5$ and 1.3 , respectively).

In mechanism of action studies on selected diterpenoid alkaloids, the $\mathrm{C}_{20}$-diterpenoid alkaloid derivatives $\mathbf{8 1}$ and $\mathbf{9 6}$ showed important suppressive effects against Raji cells. Further study indicated that $\mathbf{9 6}$ inhibited extracellular signal-regulated kinase phosphorylation but induced enhanced phosphoinositide 3 kinase phosphorylation, leading to accumulation of Raji cells in the G1 or sub G1 phase. ${ }^{33}$ More investigation is certainly warranted.

In summary, we have synthesized acylated derivatives of various $\mathrm{C}_{19^{-}}$and $\mathrm{C}_{20^{-}}$-diterpenoid alkaloids. Totally, 108 natural alkaloids and their derivatives were evaluated against four tumor cell lines. Eighty-seven compounds were non-toxic $\left(\mathrm{GI}_{50}>20 \mu \mathrm{M}\right)$, and ten compounds showed mild antiproliferative effects $\left(\mathrm{GI}_{50}=10-20 \mu \mathrm{M}\right)$. Except for 33, all of the most active compounds were hetisine-type $\mathrm{C}_{20}$-diterpenoid alkaloids with two different substitution patterns, C-11 and C-11,15. Compounds 56, 58, 61, 69, 70, 79, 89, 93, 94, 98 and $\mathbf{1 0 7}$, which are acylated or tritylated at the $\mathrm{C}-11$ hydroxyl, exhibited the greatest potency over all four tested cell lines, including multidrug-resistant KB-VIN. These results demonstrate that modified hetisine-type $\mathrm{C}_{20}$-diterpenoid alkaloids are not substrates of $\mathrm{P}$-gp and are effective against multi-drug resistant tumors. These promising new lead compounds merit continued studies to evaluate their potential as antitumor agents, particularly with enhanced resistant tumor selectivity. In addition, our results from modification-based antitumor activity studies can be used for further development of anticancer drugs overcoming a multidrug-resistant phenotype.

\section{Supplementary Material}

Refer to Web version on PubMed Central for supplementary material. 


\section{Acknowledgments}

This work was supported by NIH grant CA177584 from the National Cancer Institute awarded to K. H. Lee.

\section{References}

1. Wang, FP.; Chen, QH. The $\mathrm{C}_{19}$-diterpenoid alkaloids. In: Cordell, GA., editor. The Alkaloids. Vol. 69. New York: Elsevier Science; 2010. p. 1

2. Wang FP, Chen QH, Liu XY. Nat Prod Rep. 2010; 27:529. [PubMed: 20336236]

3. Amiya, T.; Bando, H. Aconitum alkaloids. In: Brossi, A., editor. The Alkaloids. Vol. 34. San Diego: Academic Press; 1988. p. 95

4. Pelletier SW, Page SW. Nat Prod Rep. 1984; 1:375.

5. Pelletier SW, Page SW. Nat Prod Rep. 1986; 3:451. [PubMed: 3547189]

6. Chodoeva A, Bosc JJ, Guillon J, Decendit A, Petraud M, Absalon C, Vitry C, Jarry C, Robert J. Bioorg Med Chem. 2005; 13:6493. [PubMed: 16081293]

7. de Ines C, Reina M, Gavin JA, Gonzalez-Coloma A. Zeitschrift für Naturforschung C. 2006; 61c:11.

8. Hazawa M, Wada K, Takahashi K, Mori T, Kawahara N, Kashiwakura I. Invest New Drugs. 2009; 27:111. [PubMed: 18551247]

9. Hazawa M, Wada K, Takahashi K, Mori T, Kawahara N, Kashiwakura I. Invest New Drugs. 2011; 29:1. [PubMed: 19784550]

10. Wada K, Hazawa M, Takahashi K, Mori T, Kawahara N, Kashiwakura I. J Nat Prod. 2007; 70:1854. [PubMed: 18044843]

11. Wada K, Hazawa M, Takahashi K, Mori T, Kawahara N, Kashiwakura I. J Nat Med. 2011; 65:43. [PubMed: 20706796]

12. Wada K, Ohkoshi E, Morris-Natschke SL, Bastow KF, Lee KH. Bioorg Med Chem Lett. 2012; 22:249. [PubMed: 22142543]

13. Bando H, Kanaiwa Y, Wada K, Mori T, Amiya T. Heterocycles. 1981; 16:1723.

14. Bando H, Wada K, Amiya T, Fujimoto Y, Kobayashi K. Chem Pharm Bull. 1988; 36:1604.

15. Mori T, Bando H, Kanaiwa Y, Wada K, Amiya T. Chem Pharm Bull. 1983; 31:2884.

16. Wada K, Bando H, Mori T, Wada R, Kanaiwa Y, Amiya T. Chem Pharm Bull. 1985; 33:3658.

17. Wada K, Bando H, Watanabe M, Mori T, Amiya T. Chem Pharm Bull. 1985; 33:4717.

18. Wada K, Bando H, Kawahara N, Mori T, Murayama M. Biol Mass Spect. 1994; 23:97.

19. Bando H, Wada K, Amiya T, Kobayashi K, Fujimoto Y, Sakurai T. Heterocycles. 1987; 26:2623.

20. Wada K, Kawahara N. Helv Chim Acta. 2009; 92:629.

21. Wada K, Bando H, Amiya T. Heterocycles. 1985; 23:2473.

22. Wada K, Bando H, Amiya T, Kawahara N. Heterocycles. 1989; 29:2141.

23. Wada K, Ishizuki S, Mori T, Bando H, Murayama M, Kawahara N. Biol Pharm Bull. 1997; 20:978. [PubMed: 9331980]

24. Wada K, Mori T, Kawahara N. Chem Pharm Bull. 2000; 48:660. [PubMed: 10823703]

25. Bando H, Wada K, Tanaka J, Kimura S, Hasegawa E, Amiya T. Heterocycles. 1989; 29:1293.

26. Wada K, Yamamoto T, Bando H, Kawahara N. Phytochemistry. 1992; 31:2135.

27. Wada K, Mori T, Kawahara N. Chem Pharm Bull. 2000; 48:1065. [PubMed: 10923842]

28. Wada K, Ishizuki S, Mori T, Fujihira E, Kawahara N. Biol Pharm Bull. 1998; 21:140. [PubMed: 9514608]

29. Wada K, Ishizuki S, Mori T, Fujihira E, Kawahara N. Biol Pharm Bull. 2000; 23:607. [PubMed: 10823674]

30. Wada K, Bando H, Wada R, Amiya T. Shoyakugaku Zasshi. 1989; 43:50.

31. Wada K, Bando H, Kawahara N. Heterocycles. 1990; 31:1081.

32. Skehan P, Storeng R, Scudiero D, Monks A, McMahon J, Vistica D, Warren JT, Bokesch H, Kenney S, Boyd MR. J Natl Cancer Inst. 1990; 82:1107. [PubMed: 2359136] 
33. Hazawa M, Takahashi K, Wada K, Mori T, Kawahara N, Kashiwakura I. Invest New Drugs. 2011; 29:1. [PubMed: 19784550] 


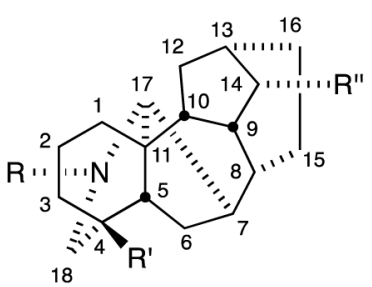

$\mathrm{C}_{18}$-Diterpenoid alkaloids

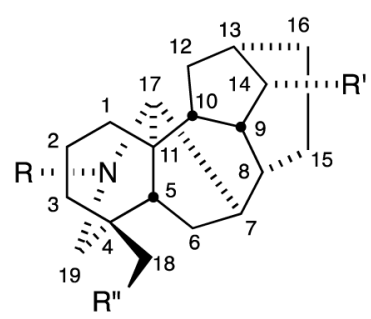

$\mathrm{C}_{19}$-Diterpenoid alkaloids
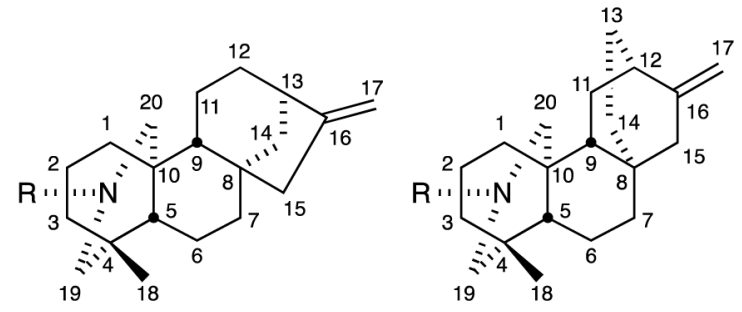

$\mathrm{C}_{20}$-Dterpenoid alkaloids

Figure 1.

General structures and numbering systems for $\mathrm{C}_{18^{-}}, \mathrm{C}_{19^{-}}$, and $\mathrm{C}_{20^{-}}$-diterpenoid alkaloids. 

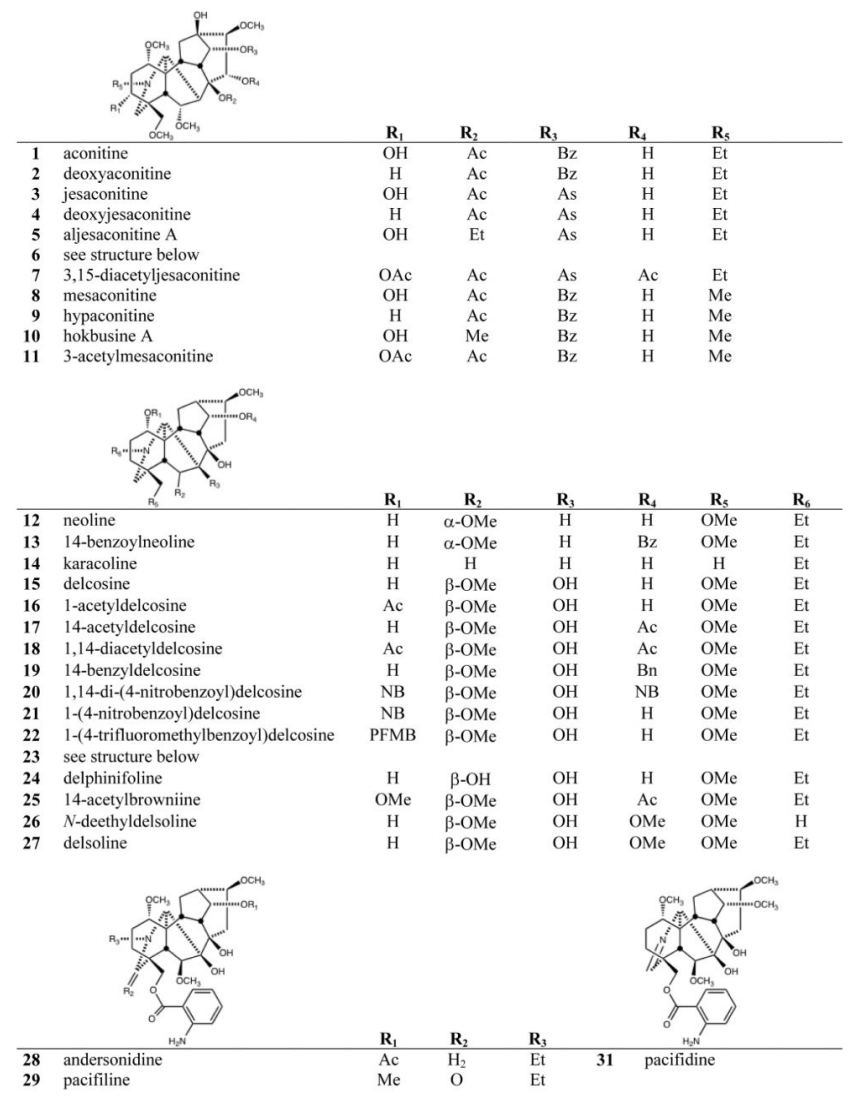

Bioorg Med Chem Lett. Author manuscript; available in PMC 2016 April 01. 
30 pacifinine

Me $\quad \mathrm{O} \quad \mathrm{H}$

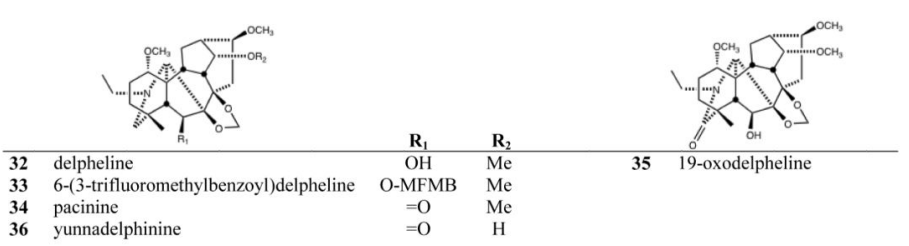

36 yunnadelphinin
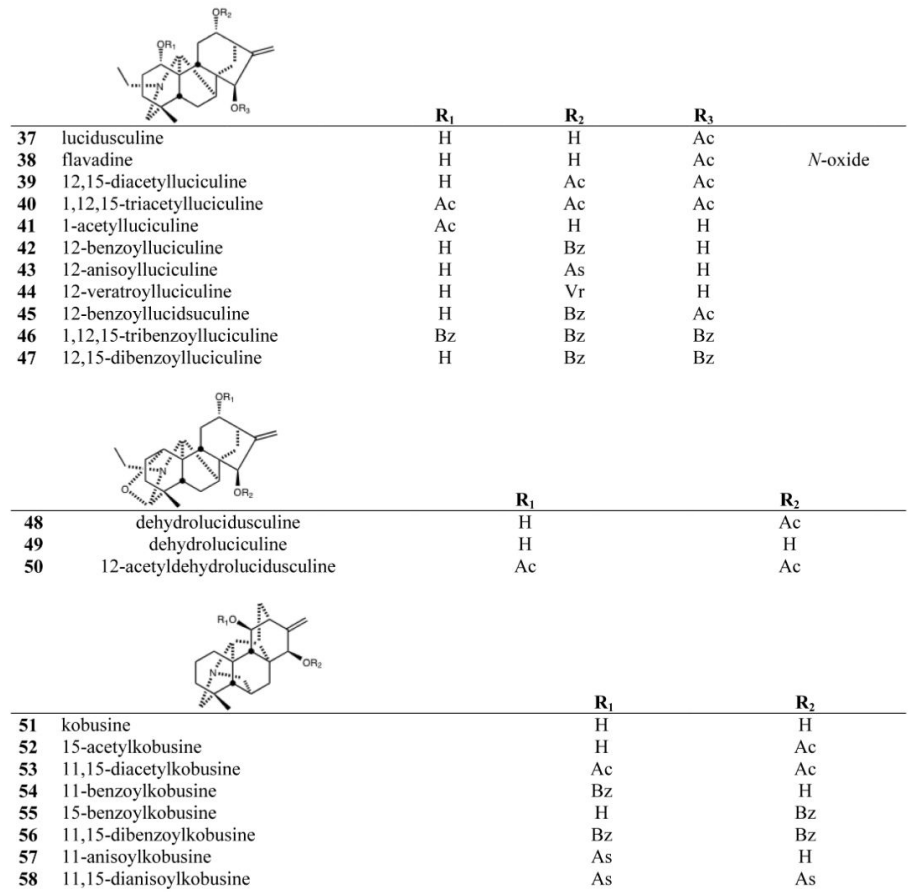


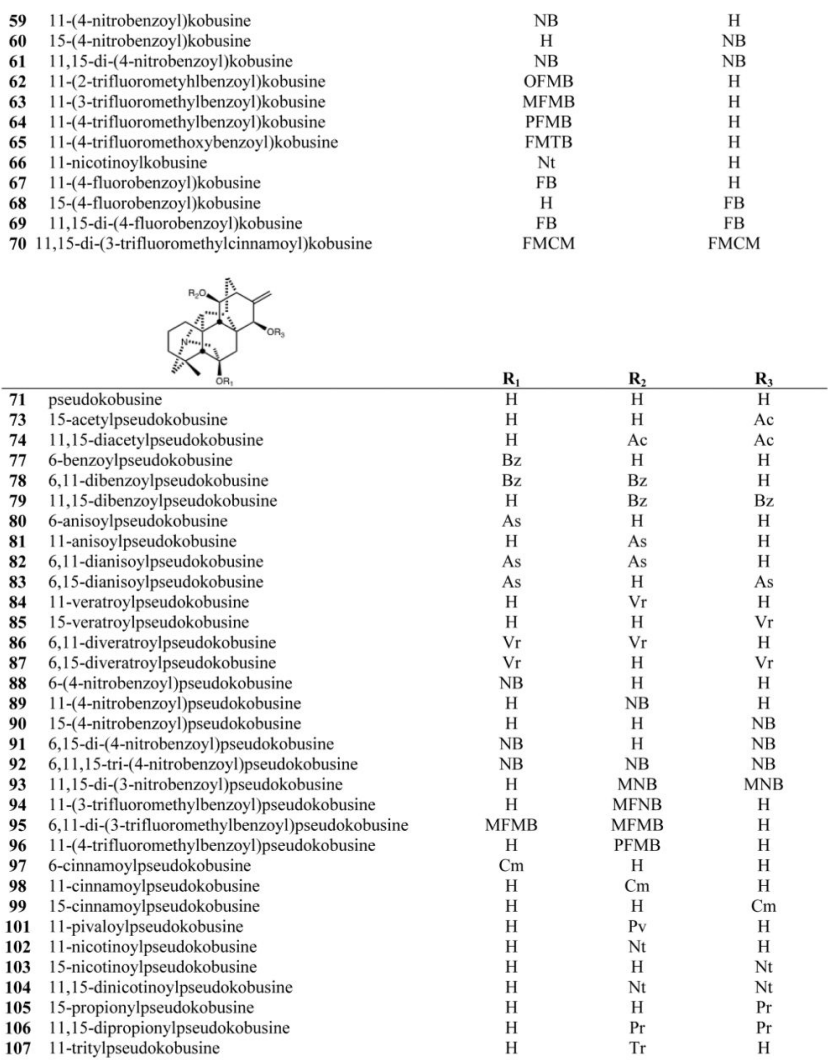




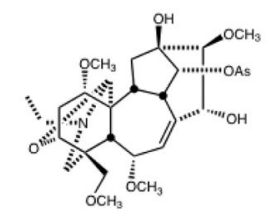

secojesaconitine

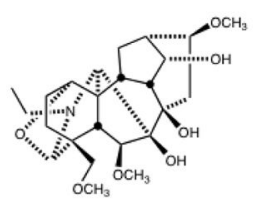

23 18-methoxygadesine

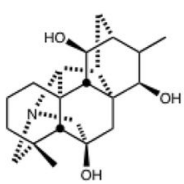

108 dihydropseudokobusine

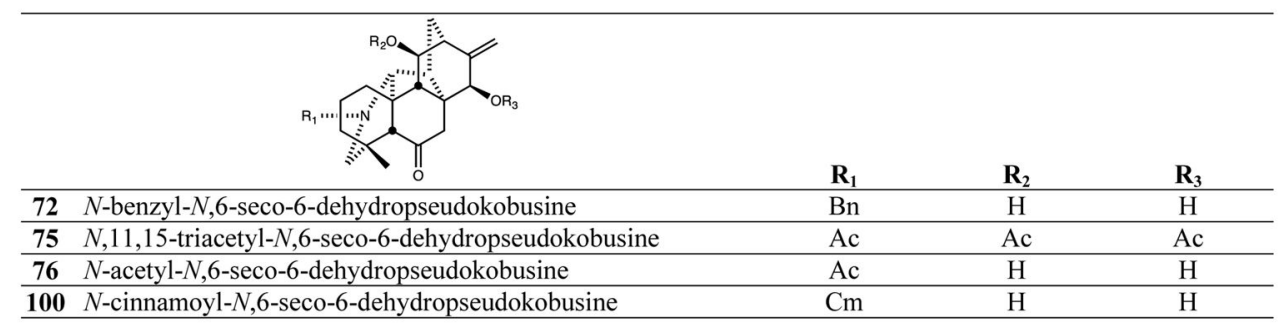

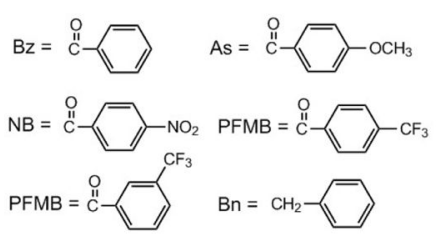
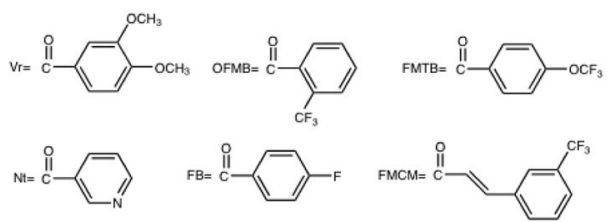

$\mathrm{MNB}=\mathrm{CI}$

$\mathrm{PV}=\mathrm{O} \underset{\mathrm{CH}}{\mathrm{O}} \stackrel{\mathrm{CH}}{\mathrm{CH}_{3}} \mathrm{CH}_{3} \mathrm{Pr}_{\mathrm{H}}=\stackrel{\mathrm{O}}{\mathrm{O}}-\mathrm{CH}_{2} \mathrm{CH}_{3}$<smiles>CC1(c2ccccc2)C2C=CC(C2)C1(C)c1ccccc1</smiles>

Figure 2.

Structures of compounds 1-108 


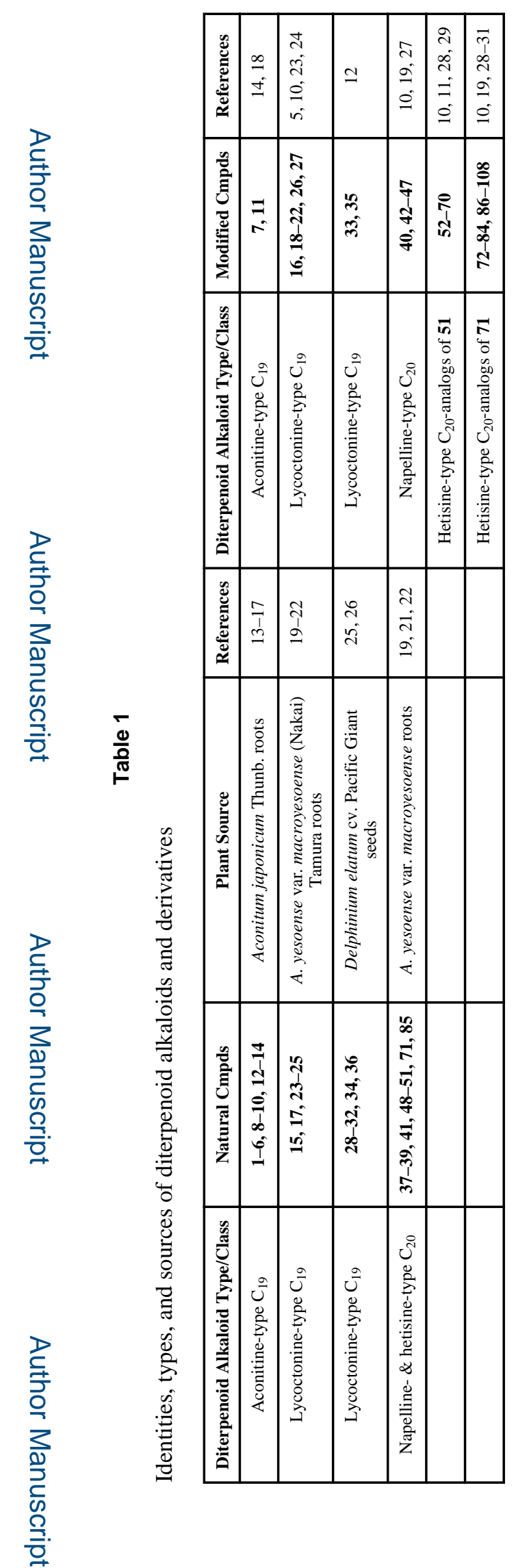

Bioorg Med Chem Lett. Author manuscript; available in PMC 2016 April 01. 


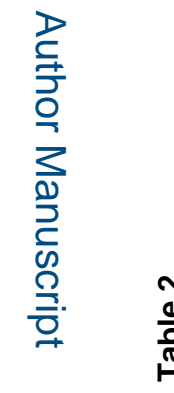

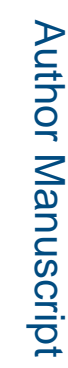

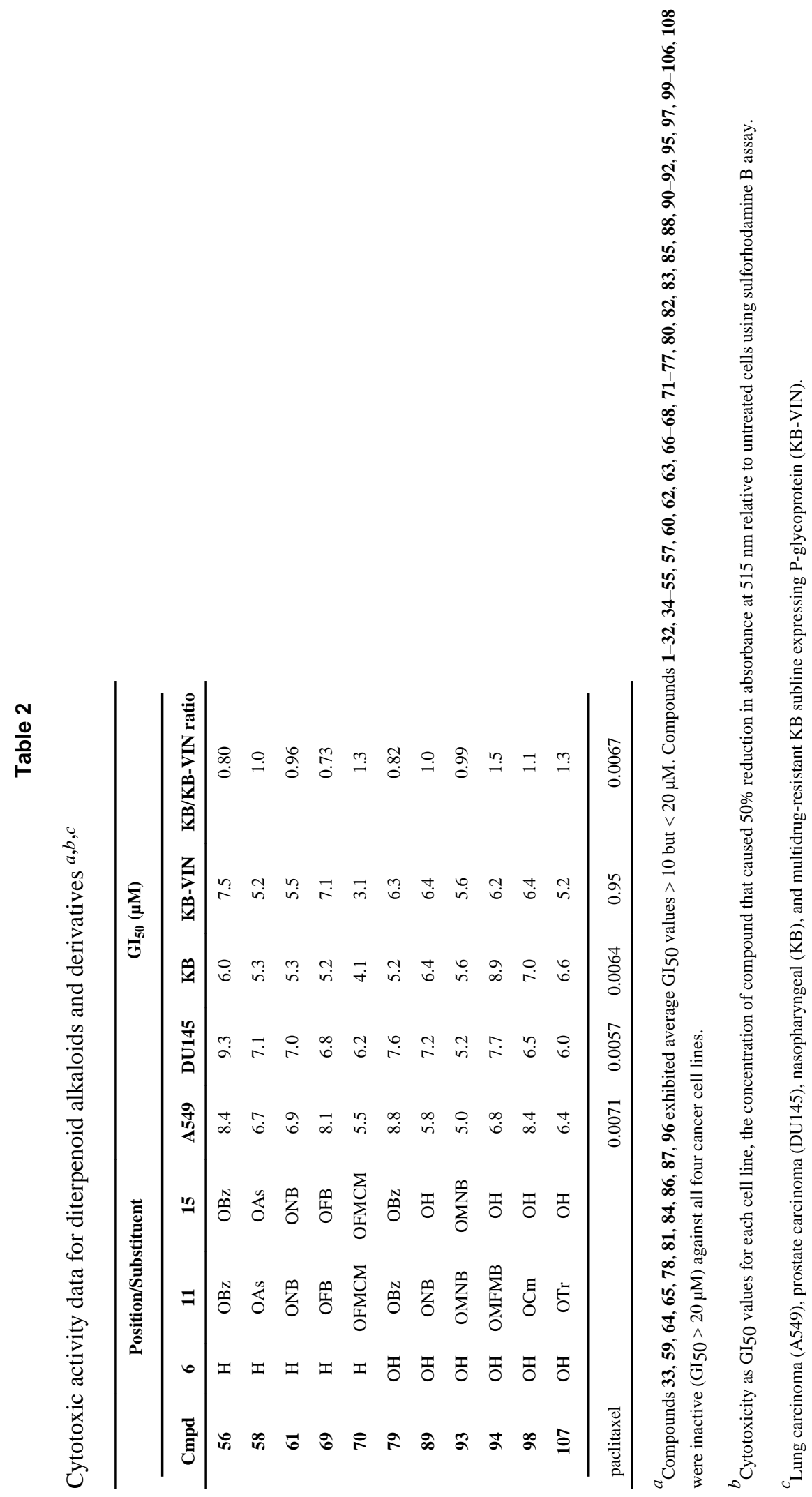

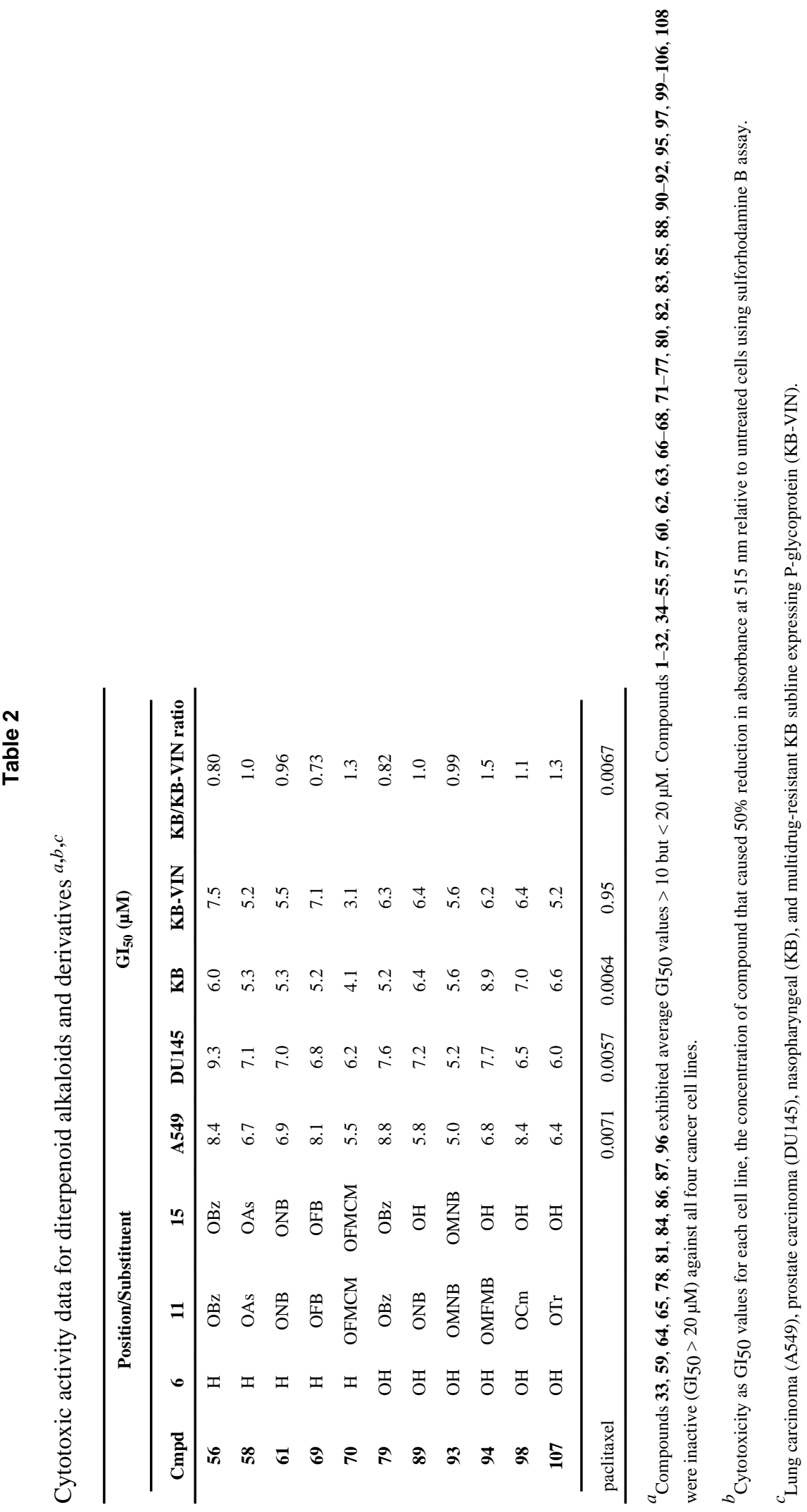

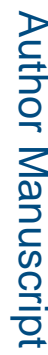

